\title{
Angka Kejadian Koagulasi Intravaskular Diseminata pada Pneumonia
}

\author{
Marissa Tania Stephanie Pudjiadi, Mardjanis Said, Irawan Mangunatmadja, \\ Hidra Irawan Satari, H F Wulandari, Murti Andriastuti \\ Departemen Ilmu Kesehatan Anak Fakultas Kedokteran Universitas Indonesia/Rumah Sakit Cipto \\ Mangunkusumo, Jakarta
}

\begin{abstract}
Latar belakang. Pneumonia merupakan penyebab kematian utama pada bayi dan balita di negara berkembang. Sitokin pada pneumonia yang diproduksi akibat inflamasi paru secara berlebihan. Sehingga menyebabkan kaskade koagulasi sistemik teraktivasi yang berakhir pada trombosis sistemik yang akan menyebabkan keadaan kritis dan seringkali berakhir dengan kematian.

Tujuan. Mengetahui profil koagulasi dan prevalensi koagulasi intravaskular diseminata (KID) pada pasien pneumonia yang dirawat inap.

Metode. Studi deskriptif analitik dengan desain potong lintang dilakukan di ruang rawat Departemen Ilmu Kesehatan Anak RSCM antara 1 Februari 2010 sampai 28 Februari 2011.

Hasil. Tiga puluh enam persen subjek penelitian mengalami trombositopenia, 13,4\% mengalami pemanjangan protombine time (PT), dan 19,6\% mengalami penurunan kadar fibrinogen. Didapatkan $83,5 \%$ subjek penelitian memiliki kadar D-dimer yang tinggi dan $64,9 \%$ di antaranya meningkat sangat tinggi. Kejadian KID 17,5\% subjek dan seluruhnya mengalami perdarahan. Pada $88,2 \%$ pasien KID mengalami trombositopenia dengan rasio prevalens 32,5 (95\% IK 6,70-157,57).

Kesimpulan. Profil koagulasi pasien pneumonia yang dirawat di Departemen Ilmu Kesehatan Anak RSCM 36\% mengalami trombositopenia, pemanjangan PT 13,4\%, penurunan kadar fibrinogen 19,6\%, dan peningkatan kadar D-dimer 83,5\% . Koagulasi intravaskular diseminata terjadi 17,5\% (17/97) pasien pneumonia yang dirawat. Sari Pediatri 2012;14(1):52-6.
\end{abstract}

Kata kunci: pneumonia, koagulasi intravaskular diseminata, trombositopenia

$\mathrm{P}$ neumonia merupakan penyebab kematian utama pada bayi dan balita di negara berkembang. Hasil Riset Kesehatan Dasar tahun 2007 mencatat prevalensi pneumonia

\section{Alamat korespondensi:}

Dr. Marissa Tania Stephanie Pudjiadi, Sp.A, Jl. Yusuf Adiwinata No. 62-64. Telp. (021) 8199766, Jakarta Pusat. Email: Marissa_Pudjiadi@ yahoo.com pada anak $11,2 \%$. Pneumonia merupakan penyebab kematian kedua setelah diare pada balita yaitu sebesar $15,5 \%{ }^{1}$

Manifestasi klinis pneumonia bervariasi mulai dari keterlibatan sebagian lobus paru sampai berupa sindrom sepsis berat. ${ }^{2}$ Variasi tersebut merupakan hasil akhir dari interaksi antara agen dan pejamu yang diperantarai oleh sitokin. Sitokin akan mengefektifkan dan meredakan inflamasi sesuai kebutuhan tubuh pasien, 
namun di saat yang bersamaan dapat mengaktifkan sistem koagulasi dengan hasil akhir suatu trombosis sistemik. Beberapa penelitian mengemukakan trombosis sistemik yang terjadi pada pneumonia baik dalam bentuk thrombotic thrombocytopenia purpura (TTP) maupun koagulasi intravaskular diseminata yang menyebabkan pasien berada dalam keadaan kritis dan berakhir pada kematian. ${ }^{3}$

Penelitian kami diharapkan dapat memberikan data mengenai profil koagulasi pasien pneumonia serta kejadian trombosis sistemik yang terjadi. Oleh karena angka kejadian TTP yang rendah (prevalensi TTP di Amerika tahun 2004 adalah 6,5/1.000.000 kejadian per tahun) dan angka kejadian KID yang tinggi (insidens KID tahun 2004 di Jepang 1,72\% dan di Turki $1 \%$ per tahun), maka penelitian kami hanya difokuskan untuk mencari kejadian KID sebagai bentuk trombosis sistemik yang terjadi. ${ }^{4-6}$ Selain itu, tata laksana yang agresif dilakukan pada pasien dengan KID dekompensasi maka penelitian hanya difokuskan untuk mencari kejadian KID fase dekompensasi. Diharapkan penelitian kami dapat membuat para dokter lebih waspada terhadap terjadinya KID pada pasien pneumonia.

\section{Metode}

Studi deskriptif analitik dengan desain potong lintang dilakukan di ruang rawat Departemen Ilmu Kesehatan Anak RSCM antara 1 Februari 2010 sampai 28 Februari 2011. Populasi target penelitian adalah semua pasien anak dengan pneumonia di Indonesia. Populasi terjangkau adalah semua pasien anak dengan pneumonia yang dirawat di ruang rawat Departemen Ilmu Kesehatan Anak RSCM. Subjek penelitian adalah semua anak pada populasi terjangkau yang memenuhi kriteria inklusi dan eksklusi. Kriteria inklusi semua pasien anak dengan diagnosis pneumonia yang dirawat di ruang rawat dengan usia antara 2 bulan-18 tahun dan tidak diikutsertakan apabila oangtua pasien tidak bersedia ikut dalam penelitian. Jumlah subyek 97 pasien, dihitung berdasarkan rumus besar sampel untuk penelitian deskriptif kategorik.

Penelitian diawali dengan mendeteksi seluruh pasien pneumonia yang sesuai dengan kriteria inklusi dan eksklusi. Kemudian dilakukan penilaian profil koagulasi pasien yaitu menilai jumlah trombosit, waktu protrombin, kadar D-dimer, dan kadar fibrinogen.
Pemeriksaan laboratorium dilakukan di laboratorium Patologi Klinik RSCM yang memiliki akreditasi peringkat A sesuai dengan akreditasi rumah sakit Kementrian Kesehatan tahun 2005.

Data diolah dengan menggunakan program SPSS 15. Interpretasi hasil berupa proporsi dan dihitung dalam bentuk rasio prevalens serta interval kepercayaan. Data disajikan dalam bentuk tekstular dan tabular.

Batasan operasional,

1. Pneumonia adalah infeksi akut parenkim paru yang mencakup infeksi alveolus dan jaringan interstitial paru yang ditandai dengan batuk, peningkatan suhu $\geq 38^{\circ} \mathrm{C}$, takipnea (Lampiran 1), peningkatan usaha inspirasi (retraksi, nafas cuping hidung, atau merintih), ${ }^{7}$ serta sudah dikonfirmasi oleh dokter anak Divisi Respirologi RSCM.

2. Profil koagulasi sistemik adalah gambaran hasil laboratorium hematologi yang mencakup indikator penilaian KID. Profil koagulasi sistemik yang dicari dalam penelitian ini terdiri dari trombosit, PT, D-dimer, dan fibrinogen.

3. Koagulasi intravaskular diseminata adalah pasien dengan jumlah skor $\geq 5$, pada penilaian sebagai berikut,

- Jumlah trombosit $(/ \mu \mathrm{L})$

$$
>100.000=0,50.000-100.000=1 \text {, dan }
$$$$
<50.000 / \mu \mathrm{L}=2 \text {. }
$$

- Kadar D-dimer $(\mu \mathrm{g} / \mathrm{L})$

$$
0-500=0,500-1000=2 \text {, dan }>1000=3
$$

- Pemanjangan PT (detik)

Memanjang $<3=0,3-6=1$, dan $>6=2$

- Kadar fibrinogen $(\mathrm{mg} / \mathrm{dL})$

$>100=0, \leq 100=1$

4. Sepsis adalah sebuah kondisi yang menggambarkan respon inflamasi sistemik akibat infeksi dalam darah, yang ditandai dengan suhu $<35^{\circ} \mathrm{C}$ atau $>39^{\circ} \mathrm{C}$, takikardia dan takipnea (sesuai usia pasien), jumlah leukosit $<2.000 / \mu \mathrm{L}$ atau $>12.000 /$ $\mu \mathrm{L}$, terdapat disfungsi lebih dari satu organ, serta bukti infeksi seperti peningkatan parameter infeksi spesifik antara lain prokalsitonin $>2 \mathrm{ng} / \mathrm{dL}$, CRP $>50 \mathrm{mg} / \mathrm{L}$, atau biakan darah positif. ${ }^{8-9}$

5. Jumlah trombosit: trombositopenia $<100.000 / \mu \mathrm{L}$, trombositosis $>300.000 / \mu \mathrm{L}{ }^{8}$

6. PT: normal $\leq 3$ detik, memanjang $>3$ detik (terhadap kontrol). ${ }^{8}$

7. Kadar D-dimer: normal 0-500 $\mu \mathrm{g} / \mathrm{L}$, meningkat sedang $>500-1000 \mu \mathrm{g} / \mathrm{L}$, meningkat tinggi $>1.000$ - 
$3.000 \mu \mathrm{g} / \mathrm{L}$, meningkat sangat tinggi $>3.000$ $\mu \mathrm{g} / \mathrm{L} .^{8}$

8. Kadar fibrinogen: normal: $>100 \mathrm{mg} / \mathrm{dL}$, menurun: $\leq 100 \mathrm{mg} / \mathrm{dL}^{.}{ }^{8}$

\section{Hasil}

Didapatkan 105 pasien pneumonia yang dirawat di ruang rawat Departemen IKA RSCM, dua pasien menolak untuk ikut penelitian, satu pasien tidak berhasil diambil darah, dan data lima pasien tidak sesuai dengan inklusi penelitian. Sebagai hasil akhir, diperoleh 97 subjek pasien pneumonia yang memenuhi kriteria penelitian.

\section{Gambaran hasil laboratorium hematologi}

Profil koagulasi subjek penelitian disajikan pada Tabel 2. Di antara 81 subjek yang memiliki kadar D-dimer tinggi 65 subjek memiliki kadar yang sangat tinggi.

\section{Kejadian KID}

Kejadian KID ditemukan pada 17 subjek penelitian. Seluruh pasien yang mengalami kejadian KID pada saat yang bersamaan juga memiliki diagnosis tertera pada Tabel 3.

Hanya sepsis yang secara langsung dapat menyebabkan KID. ${ }^{10}$ Penyakit penyerta tersebut dapat ditemukan secara kombinasi yaitu pasien mengalami

Tabel 1. Karakteristik subyek penelitian

\begin{tabular}{lcc}
\hline Variabel & Jumlah (pasien) & Persentase (\%) \\
\hline Jenis kelamin & 48 & \\
$\quad$ Laki-laki & 49 & 49,5 \\
$\quad$ Perempuan & & 50,5 \\
Usia & 48 & 58,8 \\
$\quad 2-<12$ bulan & 39 & 14,4 \\
$\quad 1-5$ tahun & 10 & 16,5 \\
$\quad>5$ tahun & & \\
Penyakit penyerta & 12 & 12,4 \\
$\quad$ Tidak ada & & \\
$\quad$ Penyakit penyerta & 16 & 16,5 \\
$\quad$ Sepsis & 69 & 71,1 \\
$\quad$ Lain-lain & 97 & 100 \\
\hline Jumlah & & \\
\hline
\end{tabular}

\section{Karakteristik subjek penelitian}

Secara keseluruhan dari 97 subjek didapatkan perbandingan yang hampir sama antara perempuan dan laki-laki yaitu 1,15:1. Median usia awitan satu tahun dengan rentang 2 bulan-15 tahun. Ditemukan 85 pasien menderita penyakit penyerta dengan 16 pasien di antaranya mengalami sepsis.

Tabel 2. Profil koagulasi subjek penelitian

\begin{tabular}{lcc}
\hline Profil koagulasi & Proporsi & Frekuensi (\%) \\
\hline Trombositopenia & $35 / 97$ & 36 \\
Pemanjangan PT & $13 / 97$ & 13,5 \\
Penurunan fibrinogen & $19 / 97$ & 19,6 \\
Peningkatan D-dimer & $81 / 97$ & 83,5 \\
\hline
\end{tabular}

Tabel 3. Penyakit penyerta pada pasien pneumonia dengan KID

\begin{tabular}{lc}
\hline Penyakit penyerta & Proporsi \\
\hline Sepsis & $6 / 17$ \\
Gizi kurang & $6 / 17$ \\
Gagal tumbuh & $3 / 17$ \\
Gizi buruk marasmik & $2 / 17$ \\
Penyakit jantung bawaan & $2 / 17$ \\
AIDS & $2 / 17$ \\
Diare akut & $1 / 17$ \\
Gagal ginjal akut & $2 / 17$ \\
Gagal ginjal kronis & $1 / 17$ \\
Gastroesofageal reflux disease & $1 / 17$ \\
Sindrom down & $1 / 17$ \\
\hline
\end{tabular}


gagal tumbuh dan atrioseptal defect, sepsis dan gagal ginjal akut, acquired immunodeficiency syndrome (AIDS) dengan gizi buruk marasmik dan sepsis, AIDS dan gizi kurang, sindrom Down, ventrikuloseptal deffect, dan gagal tumbuh, astroesofageal reflux disease dan gizi kurang, diare akut dan gizi kurang, gagal tumbuh dan gizi kurang, gagal ginjal kronis, gizi kurang, gizi buruk marasmik, sepsis.

Seluruh pasien yang mengalami KID juga mengalami perdarahan pada saat dilakukan pengambilan darah sampai 7 hari setelahnya. Perdarahan yang terjadi berupa petekie, Uji darah samar yang positif, melena, perdarahan dari NGT, dan ETT, serta hematuria. Didapatkan 15/17 pasien dengan KID mengalami trombositopenia $(.000-58.000 / \mu \mathrm{L})$ dengan rasio prevalens $32,5(95 \% \mathrm{IK}$ 6,70-157,57).

Seluruh subjek penelitian memiliki kadar D-dimer yang meningkat tinggi walaupun pemeriksaan dilakukan pada hari pertama diagnosis pneumonia. Peningkatan kadar D-dimer tersebut terbagi dua yaitu $13 / 17$ subjek meningkat sangat tinggi yaitu antara $3.100-20.000 \mu \mathrm{g} / \mathrm{L}$ dan yang tersisa meningkat tinggi antara $900-2.900 \mu \mathrm{g} / \mathrm{L}$.

Tata laksana KID berupa transfusi trombosit dan plasma darah, heparinisasi, antibiotik yang sesuai dengan biakan darah, serta tata laksana suportif lain seperti pemberian oksigenasi yang adekuat, memperbaiki status volemik pasien dan mengatasi syok, memperbaiki gangguan gas darah, serta nutrisi yang adekuat, dan mencegah kegagalan multi organ. Pengukuran kadar AT III dan protein C serta koreksi kadar kedua parameter tersebut belum dilakukan. ${ }^{11}$ Delapan dari 17 pasien pneumonia yang mengalami KID meninggal dunia.

\section{Pembahasan}

Diagnosis pneumonia sering sekali ditemukan pada praktek sehari-hari. Spektrum klinis pneumonia bervariasi ringan hingga berat. Selama ini dalam menghadapi kasus pneumonia sebagian besar dokter mengira bahwa kasus yang dihadapi adalah kasus infeksi yang hanya terisolasi di paru. Namun Nguyen dkk ${ }^{11}$ dan Chung $\mathrm{dkk}^{12}$ dalam penelitiannya memperlihatkan bahwa sebagian besar kasus pneumonia pada saat bersamaan juga mengalami suatu proses sistemik. Penelitian kami hanya menilai trombosis sistemik berupa KID fase dekompensasi sehingga cakupan trombosis sistemik yang terdeteksi pada pasien pneumonia tidak lengkap.

Sebagian pasien pneumonia yang mengalami KID juga didiagnosis sepsis. Keadaan sepsis menjadi khusus karena sepsis secara terpisah dapat menyebabkan gangguan koagulasi, namun sepsis tidak dimasukkan ke dalam kriteria eksklusi karena pneumonia dapat menjadi fokus infeksi sepsis terutama pada usia muda. Penyakit penyerta yang terdapat pada studi kami bukan merupakan etiologi KID. ${ }^{10}$ Semua pasien pneumonia diberikan pengobatan sesuai dengan Standar Pelayanan Medis Departemen Ilmu Kesehatan Anak RSCM, termasuk dalam hal pemilihan antibiotik dan terapi oksigen.

Kejadian trombositopenia terjadi pada hampir seluruh pasien pneumonia yang mengalami KID, hanya dua pasien yang memiliki jumlah trombosit di atas $100.000 / \mu \mathrm{L}$. Pengambilan data dari kedua pasien dilakukan pada hari pertama diagnosis pneumonia. Keadaan trombositopenia pada pneumonia sebagai faktor risiko terjadi KID. Trombositopenia pada pasien yang mengalami KID sesuai dengan konsumtif koagulopati pada patofisiologi KID.

Pemanjangan PT terdeteksi pada 2 dari 17 subjek. Pemanjangan PT pada keadaan KID terjadi setelah kaskade pembekuan darah terganggu sehingga pada pengambilan data yang terlalu dini tidak akan didapatkan pemanjangan PT.

Berbeda dengan PT, seluruh subjek memiliki kadar D-dimer yang sangat tinggi. Peningkatan yang tinggi sudah ditemukan sejak hari pertama diagnosis pneumonia. Kadar D-dimer meningkat pada pneumonia dipakai secara luas sebagai indikator KID. Peningkatan D-dimer sebagai indikator KID lebih sensitif apabila dibandingkan dengan pengukuran PT dan activated partial thromboplastin time (aPTT). ${ }^{10-13}$

Pada pasien kritis, kadar D-dimer sering digunakan untuk mengidentifikasi aktivasi kaskade koagulasi sistemik. Koagulasi intravaskular diseminata sudah mulai terjadi sebelum gejala klinis timbul atau disebut juga KID fase kompensasi dan kadar D-dimer telah meningkat. ${ }^{13}$ Dhainaut $\mathrm{dkk}^{14}$ mengemukakan bahwa peningkatan pada PT dan D-dimer berkorelasi dengan mortalitas pada 28 hari ke depan. Temuan lain oleh Shitrit $\mathrm{dkk}^{15}$ adalah hubungan paralel antara peningkatan kadar D-dimer 24 dan 48 jam pertama dengan luaran pasien yang buruk.

Terapi KID yang diberikan sesuai dengan terapi KID yang masih dianut sampai saat ini. Namun akhirakhir ini, para ahli mencoba melakukan pengukuran 
dan koreksi terhadap kadar AT III dan protein C pada pasien KID, Terapi terbaru belum dilakukan secara rutin di Departemen Ilmu Kesehatan Anak RSCM. ${ }^{11}$

Hasil penelitian yang dilakukan sejalan dengan penelitian yang dilakukan oleh Nguyen dkk, ${ }^{11}$ ditemukannya trombosis sistemik pada pasien pneumonia. Namun terdapat perbedaan jenis trombosis sistemik yang teridentifikasi, yaitu TTP pada penelitian Nguyen $\mathrm{dkk}^{11}$ dan KID pada penelitian kami.

\section{Kesimpulan}

Pada pasien pneumonia yang dirawat di Departemen Ilmu Kesehatan Anak RSCM, 36\% subjek mengalami trombositopenia, subjek mengalami pemanjangan PT 13,4\%, penurunan kadar fibrinogen 19,6\%, dan peningkatan kadar D-dimer 83,5\%. Koagulasi intravaskular diseminata $17,5 \%$ pasien pneumonia, seluruhnya memiliki penyakit penyerta serta seluruhnya mengalami perdarahan. Disarankan melakukan pemeriksaan parameter trombosis sistemik pada pasien pneumonia yang mengalami trombositopenia dan yang memiliki penyakit penyerta untuk mendeteksi KID. Perlu dilakukan suatu penelitian untuk menilai korelasi antara pneumonia dengan KID yang mencakup KID fase kompensasi, dekompensasi, dan TTP sebagai bentuk gangguan koagulasi sistemik yang terjadi akibat pneumonia.

\section{Daftar pustaka}

1. Weber M, Handy F. Action against pneumonia in children outline of a global action plan. Bul Jendela Epidemiol 2010;3:1-9.

2. Prober CG. Pneumonia. dalam: Behrman RE, Kliegman RM, Jenson HB. Editors. Nelson textbook of pediatrics. Edisi ke-6. Philadelphia: WB Saunders Company; 2000. h.761-5.

3. Moake JL. Studies on the pathophysiology of thrombotic thrombocytopenic purpura. Semin Hematol 1997;34:83-9.

4. Miller DP, Kaye JA, Shea K, Ziyadeh N, Cali D, Black
C, dkk. Incidence of thrombotic thrombocytopenic purpura/hemolytic uremic syndrome. Epidemiology 2004;15:208-15.

5. Wada H. Disseminated intravascular coagulation. Clin Chim Acta 2004;344:13-21.

6. Oren H, Cingoz I, Duman M. Disseminated intravascular coagulation in pediatric patients: clinical and laboratory features and prognostic factors influencing the survival. Pediatr Hematol Oncol 2005;22:679-88.

7. Said M. Pneumonia. Dalam: Rahajoe NN, Supriyatno B, Setyanto DB. Penyunting. Buku ajar respirologi anak. Edisi ke-1. Jakarta: Badan Penerbit IDAI; 2008. h. 35065.

8. Toh CH, Hoots WK. The scoring system of the scientific and standardisation committee on disseminated intravascular coagulation of the international society on thrombosis and haemostasis: a 5-year overview. JThromb Haemost 2007;5:604-6.

9. Brilli RJ, Goldstein B. Pediatric sepsis definition: past, present, and future. Pediatr Crit Care Med 2005;6:S6-8

10. Querol-ribelles JM, Tenias JM, Grau E, Querol-Borras JM, Climent JL, Gomez E, dkk. Plasma d-Dimer levels correlate with outcomes in patients with communityacquired pneumonia. Chest 2004;126:1087-92.

11. Nguyen T, Hall M, Yong H, Fiedor M, Bontempo F, Andrea, dkk. Microvascular thrombosis in pediatric multiple organ failure: is it a therapeutic target? Ped Crit Care Med 2001;2:187-96.

12. Chung HL, Ching LH. Thrombotic thrombocytopenic purpura as the initial presentation of Pneumocystis jiroveci pneumonia in an immunocompetent patient. Ann Hematol 2007;86:223-4.

13. Williams MT. Venous thromboembolism in the intensive care unit. Critical Care Clinics. 2003;19:185-207.

14. Dhainaut JF, Shorr AF, Maclas WL, Kollef MJ, Levi M, Reinhart K, dkk. Dynamic evolution of coagulopathy in the first day of severe sepsis: Relationship with mortality and organ failure. Crit Care Med 2005;33:341-8.

15. Shitrit D, Izbicki G, Shitrit AB, Kramer MR, Rudensky B, Sulkes J, dkk. Prognostic value of a new quantitative D-dimer test in critically ill patients 24 and $48 \mathrm{~h}$ oursfollowing admission to the intensive care unit. Blood Coagulat Fibrinol 2004;15:15-9. 